\title{
Antecedents to teachers' perceptions of the usefulness of ICTs for business education classroom instructions in Nigerian tertiary institutions
}

\author{
Dauda Dansarki Isiyaku ${ }^{1}$. Mohd Ahmad Fauzi Ayub ${ }^{1}$. Suhaida AbdulKadir ${ }^{1}$
}

Received: 13 September 2016 / Revised: 6 March 2018 / Accepted: 14 March 2018 / Published online: 22 March 2018

(c) The Author(s) 2018

\begin{abstract}
This study investigated the antecedents to Nigerian business education teachers' perceptions of the usefulness of technology in the classroom. Theoretical support for the study was based on the work of Venkatesh and Bala's (Decis Sci 39(2):273-315, 2008) Technology Acceptance Model III where computer self-efficacy and perceived enjoyment were identified as antecedents to perceived ease of use of technology while subjective norm was identified as an antecedent to perceived usefulness. The study proposed a structural model to investigate whether computer self-efficacy, perceived enjoyment, and subjective norm were antecedents to teachers' perceived usefulness of ICTs in Business Education classrooms of Nigerian tertiary institutions. The study was a survey research involving 212 teachers sampled from the Business Education faculties of 13 tertiary colleges in Northwestern Nigeria, sub-Sahara Africa. The research instrument for data collection was a structured questionnaire using items adapted from previously validated studies. The questionnaire yielded high-reliability coefficients both at the pilot and actual study stages. SPSS version 22 was used for descriptive statistics analyses, and AMOS 22 was used for structural equation modeling. The study model explained about $33 \%$ of the variance in teachers' perceptions of the usefulness of ICTs in the classroom. Two of the hypotheses of the study were statistically significant. Teachers' computer self-efficacy and perceived enjoyment of ICTs were found to significantly influence their perceived usefulness of ICTs. The study recommends that Nigerian teachers should be trained to integrate ICTs in the curriculum and be provided with ICT support services in order to help them with ICT difficulties in the classroom.
\end{abstract}

Keywords Computer self-efficacy $\cdot$ Subjective norm $\cdot$ Perceived enjoyment $\cdot$ Perceived usefulness $\cdot$ Information Communication Technologies $\cdot$ Business education $\cdot$ Nigeria $\cdot$ Africa

\section{Introduction}

The term Information Communication Technology (ICT) or its plural-Information Communication Technologies (ICTs), has been often used to describe internet technologies along with computer networks, the World Wide Web (WWW), and search engines, which are used in producing and sharing information (UNESCO 2010). ICTs comprise tools such as smart phones, tablets, laptops, personal digital assistants, projectors, and portable DVD players which can be used in facilitating classroom instructions (Pearman and

Dauda Dansarki Isiyaku

sarkidaves@gmail.com

1 Faculty of Education, Universiti Putra Malaysia, Serdang, Malaysia
Chang 2010). UNESCO (2010) had observed that ICTs can help teachers improve the quality of what they teach in the classroom, by enabling them to diversify their contents and methods and promote experimentation and innovation in the teaching and learning process. When teachers use ICTs in the classroom, their students are likely more able to cope with the divergent trends of the information age while they are in school and afterwards (Bingimlas 2009).

In education, ICTs are fundamental to creative teaching and learning and they play important roles in bridging the gaps between teacher-centered and student-centered teaching methods (Asenso-Okyere and Mekonnen 2012). Using ICTs in the classroom has the capacity of shifting the role of teachers from basically transmitting knowledge (providing primary source of information, controlling, and directing all aspects of learning) to the facilitating of the learning process (through collaboration, coaching, knowledge 
negotiation, and co-learning); hence students have more options and responsibilities for their own learning (UNESCO 2010). Using ICTs in the classroom has the capacity of shifting students' role from being passive recipients of information (reproducing knowledge and learning in solitary activities), to being active participants in the learning process (providing knowledge and learning collaboratively with others); so teachers then are no longer seen as "sages on the stage" but "guides on the side," providing students with more opportunities of being productive, creative, and innovative (UNESCO 2010). Overall, ICTs have the potential of supporting effective communication between teachers and students in ways not possible before (Dawes 2001; Bingimlas 2009). Similarly, ICTs help learners to be able to learn at their own pace and within the context of their particular environments, decreasing the limitations associated with the learning location (Pearman and Chang 2010). In essence, ICTs have the potential of bringing about important changes in ways of teaching, such as promoting participatory teaching and learning, lifelong learning as well as supporting the much-advocated student-centered learning in the current educational trend.

Despite the widespread benefits of ICTs in education, reports showed that over the past several years, most countries in the developing region of Africa (including Nigeria) were rated low across the globe in terms of ICT adoption/ uptake in education (International Telecommunication Union 2013; UNESCO 2010). Most teachers in Nigeria were not able to cope with the pace of technology adoption in the classroom owing to constraints such as lack of adequate ICT orientation and training for teachers, lack of availability of adequate ICT infrastructure in schools, and lack of stable power supply for effective ICT operational activities in schools (Asogwa 2013; Ololube 2014; Prasad et al. 2015; Anunobi 2015). Correspondingly, studies had shown most business education teachers in tertiary institutions of Nigeria did not possess the technical expertise to implement ICTs in their classrooms (Prasad et al. 2015; Anunobi 2015; Isiyaku et al. 2015; Isiyaku and Ayub 2016).

Past studies in Nigeria had used descriptive statistics methods to investigate ICT usage problems relating to poor ICT infrastructure, inadequate internet access, and shortage of skilled manpower, but studies investigating other important variables such as teachers' perceptions towards the use of ICTs were rare (Larkin and Belson 2005; Ololube 2014; Isiyaku et al. 2013). There were, however, a few studies in the African region that examined teachers' perceptions concerning the usage of ICTs, and literature on ICT use in education in other parts of the world also highlighted teachers' perceptions had a significant influence on how they used ICTs in the classroom
(Ertmer 2005; Windschitl and Sahl 2002; Venkatesh and Bala 2008).

Findings of a study conducted on 161 teachers from eight middle and high schools in both rural and urban settings of West Virginia, USA, identifying K12 teachers' attitudes towards the use of Web 2.0 technologies in their teachings, indicated while the teachers were fairly proficient in their computer and internet skills and had fairly high computer self-efficacy, their workload and a structured and standardized curriculum were inhibitors of Web 2.0 adoption (Kale and Goh 2014). However, in a finding of a qualitative study conducted in Singapore to determine how school stakeholders "make sense" of educational reforms, it was shown teachers in Singapore were consistently sharing the latest ICT applications that could be used in the classroom Reyes and Kheng (2015). Tan et al. (2017) revealed the adaptive success elements of ICT integration in Singapore's education system and explained the changes of various factors that evolved the three ICT Masterplans of the country. They included the development of human infrastructure, idea generation, idea interactions and translation, support structure, and physical infrastructure.

Hence, as opposed to what is happening in Nigeria, and the rest of Africa, the ICT integration efforts of Singapore are working as a complex adaptive system, embracing an organic perspective, learning from critics and feedbacks, and taking a long-term view for iterative improvement (Tan et al. 2017). Overall, Singapore's ICT initiative has significantly moved teachers from being teacher-centered in their teaching to being student-centered. Extant research has recognized the influence of ICT reforms on teachers' sense of agency in the classrooms around Singapore. The foregoing indicates a significant gap between the types of factors focused by researchers in the developed countries of the world in their studies, and those focused by researchers in developing countries such as Nigeria. Consistently, although there are very few studies in the African region that examined teachers' perceptions concerning the usage of ICTs; literature studies showed that teachers' perceptions had a significant influence on how they used ICTs in the classroom (Ertmer 2005; Windschitl and Sahl 2002).

Based on the foregoing studies, this study used structural equation modeling to investigate the influence of computer self-efficacy, perceived enjoyment, and subjective norm on teachers' perceived usefulness of ICTs. The study focused on these variables for three reasons. Firstly, the variables are important antecedents to teachers' intentions and behavioral performances in the use of ICTs in teaching (Becker 2001; Ertmer 2005; Windschitl and Sahl 2002; Higgins and Moseley 2001; Sugar et al. 2004) which are yet to be investigated in Nigerian ICT research literature. Secondly, literature had shown that these variables had significant influence on teachers' use 
of technology in the classroom (Venkatesh 2000; Teo et al. 2008; Sun and Zhang 2006; Huang et al. 2015); and thirdly, the study intended to confirm whether these claims were applicable to Nigerian business teachers. The current study also sought to confirm the assertion that most teachers in Nigerian tertiary institutions perceived themselves as ineffectual at implementing ICTs in the classroom (Agbonlahor 2008; David 2012; Mudasiru and Modupe 2011; Oghogho and Ezomo 2013; Olakulehin 2007), but enjoyed using these technologies to teach (Adedoja et al. 2013; Al-Haderi 2013; Echeng and Usoro 2014; Isiyaku et al. 2015), and perceived that they were not expected by their school authorities to use these tools (Dansarki et al. 2014; Ibrahim et al. 2016).

\section{Literature review}

The advent of ICTs has revolutionized the world with rapid increase in knowledge and dissemination of information that empower people to do things more easily and effectively (International Telecommunication Union 2014). This revolution overcomes the barriers of time and distance and brings about efficiency and cost-effectiveness in a world linked together as a global village (Larkin and Belson 2005; Asenso-Okyere and Mekonnen 2012). Literature studies had shown the advantages and opportunities of using ICTs in education as a crucial step in achieving sustainable development in nations (Karisiddappa 2004). However, to actualize this in developing nations of Africa, especially Nigeria-ICTs must be appropriately adopted and put to use in learning institutions. Yet, reports had shown that out of the estimated population of seven billion people in the world, only three billion have access to the Internet, and are using it; and a significant majority of the access and use emanate from Europe, America, and some parts of Asia (International Telecommunication Union 2014).

Empirical evidence had shown that although Nigeria had initiated an ICT policy in the 1990s, the country is still regressive in ICT adoption and use, especially in education (Arekete et al. 2014; Iloanusi and Osuagwu 2009; International Telecommunication Union 2012, 2013, 2014). Consistently, studies had shown most teachers in Nigerian institutions of learning did not have the capacity to integrate new technologies in the classroom (Mbaba and Shema 2012; Ubulom et al. 2011; Umoru 2012). To achieve the desired education reform in Nigeria, teachers must appropriately adopt ICTs and put them to use in their teaching activities (Onyia and Offorma 2011; Yusuf and Yusuf 2009). Hence, this study borrowed insights from Technology Acceptance Model (TAM) and its evolution to TAM II and TAM III, to investigate business education teachers' technology usage behavior in the classroom.

\section{The technology acceptance model (TAM)}

The TAM was originally proposed by Davis (1989), to predict individual adoption and use of new information technologies and addressed why users accepted or rejected information technology. The model is an adaptation of the theory of reasoned action (TRA) proposed by (Fishbein and Ajzen 1975). However, while TRA is used as a general model for investigation of diverse kinds of human behavior, TAM is specifically used for investigating technology acceptance behavior (Pituch and Lee 2006).

According to TAM, an individual's behavioral intention to use a system is determined by two beliefs: perceived usefulness (PU) and perceived ease of use (PEOU). PU is defined as the extent to which a person believes that using the system will enhance his or her job performance, and PEOU is defined as the extent to which a person believes that using the system will be free of effort (Davis et al. 1989). Accordingly, TAM theorized that perceived usefulness is also influenced by perceived ease of use because, other things being equal, the easier the system is the more useful it can be (Venkatesh and Davis 2000).

Hence, while TRA was proposed to explain and predict the behaviors of people in specific situations, the key purpose of TAM was to provide a basis to trace the impact of external variables on internal beliefs, attitudes, and intentions. It suggested that perceived ease of use (PEOU) and perceived usefulness (PU) are the two most important factors in explaining system usage (Legris et al. 2003).

\section{Technology acceptance model (TAM) 2}

On the basis of the structural components of the original version of TAM, often referred to as TAM 1, it includes perceived usefulness (PU), perceived ease of use (PEOU), attitude towards technology (AT), intention to use (IU), and actual use (U), Legris et al. (2003) observed that ten relations could potentially be examined as follows: (1) PEOU-PU; (2) PU-AT; (3) PEOU-AT; (4) PU-IU; (5) PEOU-IU; (6) AT-IU; (7)AT-U; (8) IU-U; (9) PEOU-U; and (10) PU-U. Nevertheless, Legris et al. (2003) could not find any empirical evidence to show any single study that had ever incorporated all those relations, although they were measured in at least one study, sporadically. This implied a high proportion of positive results for all the relations, but with a number of inconsistencies. These favorable results highlighted variables that were related to ICT adoption intention but they were not sufficient for the prediction of actual ICT adoption and use (Legris et al. 2003). Hence, an extension of the original TAM by Davis et al. (1989) 
was proposed by Venkatesh and Davis (2000), referred to as TAM 2, in which additional theoretical constructs were identified and theorized as the general determinants of perceived usefulness (i.e., subjective norm, image, job relevance, output quality, result demonstrability, and perceived ease of use), as well as two moderators (i.e., experience and voluntariness). The assumption by Venkatesh and Davis (2000) in TAM 2 was that subjective norm and image represented the social influence processes, while the remaining determinants (job relevance, output quality, result demonstrability, and perceived ease of use, as well as experience and voluntariness) represented system characteristics.

In developing TAM 2, Venkatesh and Davis (2000) utilized ideas drawn from the work of Kelman $(1958,1961)$ on social influence as well as the work of French and Raven (1959) on power influence, postulating that the mechanisms of social influence would play a role in interpreting social influence processes. According to Venkatesh and Davis (2000), subjective norm and image would respectively and positively influence perceived usefulness through the processes of internalization and identification. TAM 2 theorized that the effect of subjective norm on both perceived usefulness and behavioral intention would attenuate over time as users gained more experience with a system.

\section{Technology acceptance model (TAM) 3}

As one of the most widely employed models of technology adoption, the original TAM had shown high predictive potentials for IT adoption and use (Davis et al. 1989; Adams et al. 2014; Venkatesh and Davis 2000; Venkatesh and Morris 2000). However, it had been criticized for lack of actionable guidance to practitioners (Lee et al. 2003, Venkatesh and Bala 2008). Hence, some researchers had developed context-specific determinants to the two TAM constructsPU and PEOU (Venkatesh and Bala 2008). For instance, Venkatesh (2000) and Venkatesh and Davis (2000) had developed general and context-independent determinants that spanned across a broad range of systems which formed the theoretical underpinning for TAM 3 and for this study.

Venkatesh (2000) identified and theorized the general determinants of perceived ease of use, observing that the parsimony of TAM and its predictive power had given it significant universal application, but while parsimony was its strength, it was also the model's key limitation. Hence, Venkatesh (2000) supported the position of Mathieson (1991) that although TAM was predictive, its generality did not provide sufficiently needed information to create user acceptance of new systems. Similarly, Venkatesh (2000) observed that although perceived ease of use had been employed extensively in user acceptance research in general and TAM research in particular, very little had been done to understand the determinants of perceived ease of use.
Also, Venkatesh and Davis (1996) acknowledged that while being very powerful in helping to predict acceptance, one of the limitations of TAM was, it did not explain acceptance beyond suggesting the system characteristics impacted ease of use. Venkatesh and Davis (1996) also posited in order to be able to explain user acceptance and use of IT that the antecedents of the key TAM constructs must be understood. Hence, Venkatesh (2000) identified and theorized the determinants of perceived ease of use, asserting that individuals would form early perceptions of perceived ease of use of a system based on several anchors related to the individuals' general beliefs regarding computers and computer use. The anchors listed by Venkatesh (2000) were computer self-efficacy, perceptions of external control (or facilitating conditions), computer anxiety, and computer playfulness.

Furthermore, Venkatesh (2000) posited while these anchors drove initial judgments of perceived ease of use, hands-on experience with the new system would influence individuals to adjust these judgments. Accordingly, two kinds of adjustments related to system characteristics were assumed to play a role in determining perceived ease of use after individuals gained experience with the new system. These two adjustments were perceived as enjoyment and objective usability.

The models of Venkatesh and Davis (2000) and that of Venkatesh (2000) were separately developed-from the original TAM. However, as observed in Venkatesh and Bala's model (2008), not much was known about possible crossover effects between the determinants of perceived usefulness in TAM 2 and the determinant factors in the Perceived Ease of Use Model. In other words, important unanswered questions in the two models were whether the determinants of perceived usefulness could influence perceived ease of use and/or whether the determinants of perceived ease of use could influence perceived usefulness. Venkatesh and Bala (2008) observed that even though in TAM 2 Venkatesh and Davis (2000) had conducted a longitudinal study, yet attempt was not made to test the specific moderating role of experience in the model.

In an attempt to address the identified weaknesses of TAM 2, Venkatesh and Bala (2008) proposed its extension-referred to as TAM 3. Basically, Venkatesh and Bala (2008) combined TAM 2 of Venkatesh and Davis (2000) and the model of the determinants of perceived ease of use by Venkatesh (2000) to develop an integrated model of technology acceptance (TAM 3). In their new model (TAM 3), Venkatesh and Bala (2008) showed a complete nomological network of the determinants of individuals' IT adoption and use and also suggested three theoretical extensions beyond TAM 2 and the model of the determinants of perceived ease of use.

The TAM offered the present study a framework to explain teachers' perceptions of the usefulness of technology 
in Nigeria, through visualizing three variable constructs, namely, computer self-efficacy, perceived enjoyment, and subjective norm. Although this study focused on business education teachers in Nigerian tertiary institutions of learning, it is expected that the findings will be relevant to the circumstances of other teachers in other institutions of learning across the developing countries of Africa.

\section{Computer self-efficacy}

Computer self-efficacy is defined as an individual's belief or judgement that he/she has the ability to perform a specific task/job using the computer (Compeau and Higgins 1995; Venkatesh et al. 2003). Computer self-efficacy is also defined as an individual's control beliefs regarding his/her personal ability to use a computer system (Venkatesh and Bala 2008). In this study, computer self-efficacy represented teachers' judgments of their capabilities of using ICTs to facilitate classroom instructions.

Irrespective of the sophisticated nature of ICTs available, teachers' perceptions of their ability to use ICTs will influence how they use them (Kadel 2005). Cheok and Wong (2015) stated that teachers need to have adequate perception of their computer self-efficacy to be able to implement technology in the classroom.

\section{Perceived enjoyment}

Perceived enjoyment is defined as the extent to which the activity of using a specific system is perceived to be enjoyable in its own right, aside from any performance consequences resulting from system use (Venkatesh 2000). Empirical evidence had shown that teachers' perceived enjoyment of ICTs could influence their overall intention of using ICT tools in the classroom. In this study, perceived enjoyment represented the extent to which teachers perceived using ICTs in the classroom was enjoyable and full of fun.

Cheok and Wong (2015) reported positive significant correlations between user-related characteristics such as satisfaction (perceived enjoyment) and perceived usefulness. Hence, when teachers perceived that they enjoyed using ICTs in the classroom, there would be a tendency for them to want to use ICT tools and vice versa. Teachers would be more motivated to do or repeat an activity they found enjoyable much more than they would do for the same activity which was not enjoyable.

\section{Subjective norm}

Subjective norm refers to the perception of an individual that most people who are important to him would think that he should or should not perform a specific behavior (Venkatesh et al. 2003). In this study, subjective norm represented the extent to which lecturers perceived they were expected by others to use ICTs in the classroom.

Significant influences of subjective norm on individual's perception of technology were found in the works of Fishbein and Ajzen (1975) in the TRA; Ajzen (1991) in the Theory of Planned Behavior (TPB); Venkatesh and Davis (2000) in TAM2 and Venkatesh and Bala (2008) in TAM3. Teo (2010) examined the self-reported technology usage intentions of 314 pre-service teachers and found that subjective norm had significant effects on behavioral intention to use technology when mediated by perceived usefulness. In another study by Teo (2011) conducted among 592 teachers from schools in Singapore, subjective norm was found to have significant positive influence on teachers' perceived usefulness.

\section{Perceived usefulness}

Perceived usefulness is defined as the degree to which a person believes that using technology will enhance his or her job performance (Davis et al. 1989). In this study, perceived usefulness refers to teachers' assessment of how ICTs were useful to them in performing their classroom functions. For teachers to appreciate using ICTs in the classroom, they need to see that ICT tools are imperative for teaching. Individuals viewed ICTs as useful to their jobs when they perceived that the time they spent on doing their jobs could be lessened and their job performances could be improved by their use of ICTs (Teo et al. 2008; Bhatti 1970).

ICTs have the potential of facilitating new approaches to teaching and learning (Venkatesh et al. 2014). Numerous researchers had investigated the link between teachers'/ students' perceptions of the use of ICTs in the classroom and their perception of the quality of teaching/learning (Artino 2007; Dziuban et al. 2011; Lowerison et al. 2006; Keengwe 2007; Tang and Austin 2009). Nonetheless, studies addressing technology integration in Nigeria and other African countries are limited, and this is a serious concern to researchers and to the educational authorities in Africa (Averweg 2008; Erasmus et al. 2015). Currently, teachers in Nigeria are under pressure to shift from their old style of teaching and implement ICTs in the way they design, teach, and assess their courses for optimum teaching and learning experience (Echeng and Usoro 2014). Therefore, this study aimed at inspiring teachers in developing countries like Nigeria to embrace ICTs in their classrooms.

\section{Conceptual model of the study}

The conceptual model of this study (Fig. 1) was consistent with past studies on technology/ICT usage behavior that stemmed out of the works of Fishbein and Ajzen (1975) TRA; Ajzen (1985)—Theory of Planned Behavior (TPB); 


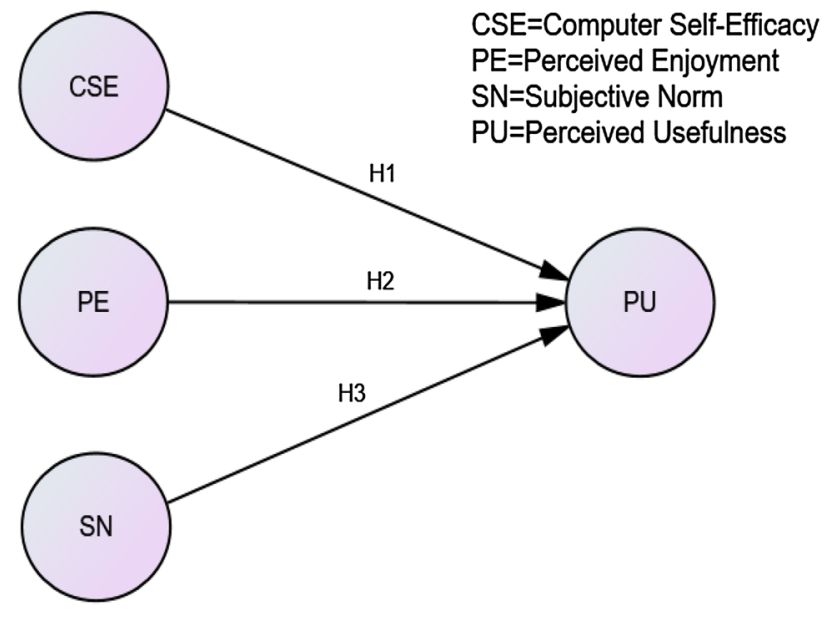

Fig. 1 Conceptual model of the study (Reproduced with permission from TAM 3 (Venkatesh and Bala 2008))

and Davis (1989) — TAM as well as Venkatesh and Davis (2000) — TAM2; Venkatesh (2000) — Model of the determinants of perceived ease of use; and Venkatesh and Bala (2008) - TAM3. The variables that constituted the model of the present study were computer self-efficacy (CSE), perceived enjoyment (PE), and subjective norm (SN), as antecedents to Perceived Usefulness (PU). This study was limited in the conceptual orientation to an investigation of teachers' perceptions regarding the usefulness of ICTs because empirical evidence had shown teachers' perceptions on technology had a significant influence on how they accepted ICTs in their classrooms (Kadel 2005). Moreover, in this study, the teachers in Nigeria were just beginning to adopt technology in their classrooms (UNESCO 2010); hence the researchers found it important to investigate how teachers valued and perceived the usefulness of these tools in their classrooms.

In a study conducted on 121 science teachers from nine districts in Selangor, Malaysia, by Ayub et al. (2016), significant positive correlations were reported between teachers' ICT abilities and their predispositions towards using technology in the classroom. Another study by Teo et al. (2009) conducted on 495 pre-service teachers from Singapore and Malaysia, showed computer self-efficacy had a significant influence on perceived usefulness. Agarwal and Karahanna (2000) had also reported computer self-efficacy was a significant determinant of perceived usefulness. Therefore, the first hypothesis in this study was:

$\mathbf{H}_{1}$ Teachers' computer self-efficacy has a direct influence on their perceptions of the usefulness of ICTs.

In a study by Negahban and Chung (2014) on a sample of 336 student teachers in a university in Southern United
States, they found teachers' perceived enjoyment influenced perceived usefulness positively. An experimental study involving two cultures (USA and Taiwan) revealed a positive relationship between perceived usefulness and perceived enjoyment in both cultures (Huang et al. 2015). Cheok and Wong (2015) also reported that user-related characteristics such as satisfaction (perceived enjoyment) were found to have positive correlations with perceived usefulness.

Perceived usefulness was measured in terms of the gradation to which a person trusts that by using a definite technology would boost his or her job routine. Teachers' perceptions of the usefulness of technology in the classroom might determine whether they accepted or rejected ICTs (Davis et al. 1989). Studies had shown teachers' perceived usefulness of technology could significantly influence their use of ICTs through their intention to use technology and their attitudes towards technology (Isiyaku et al. 2015; Pynoo and van Braak 2014). Hence, the second hypothesis of the study was:

$\mathbf{H}_{2}$ Teachers' perceived enjoyment has direct influence on their perceptions of the usefulness of ICTs.

Subjective norm is one of the most popular constructs investigated in ICT research. Although the construct was not investigated in TAM 1, Davis et al. (1989) emphasized that subjective norm should be investigated in future researches. Subjective norm was later investigated in TAM2 and TAM3, and on the same basis, this study attempted to investigate the construct in this study.

Significant influence of subjective norm on individuals' perceptions of technology was found in Ajzen (1991); Fishbein and Ajzen (1975); Venkatesh and Bala (2008); Venkatesh and Davis (2000), and Bhatti (1970) had also shown that subjective norm influenced perceived usefulness positively. Therefore, the third hypothesis of this study was:

$\mathrm{H}_{3}$ Teachers' subjective norm has direct influence on their perception of the usefulness of ICTs.

In this study, it was posited if teachers considered ICTs as useful tools in the classroom they would seek to use them, and by investigating the influence of computer self-efficacy, perceived enjoyment, and subjective norm on teachers' perceived usefulness of ICTs, the study would generate explanations regarding teachers' ICT usage behavior in Business Education classes in Nigerian educational institutions. The findings of this study would provide tertiary institutions with information and insight in order to inspire and encourage teachers to use ICTs in their educational curriculums. 


\section{Research method}

This study utilized a quantitative survey approach based on structural equation modeling (SEM) analyses in which the predictive influences of three exogenous variables (computer self-efficacy, perceived enjoyment, and subjective norm) on one endogenous variable (perceived usefulness of technology) were investigated. AMOS v22 was used to analyze the study data in three important stages, namely, assessing the confirmatory factor analysis (CFA); assessing the measurement model; and assessing the structural model (Hair et al. 2010).

\section{Sample}

A sample of 220 business education teachers in Nigeria were randomly selected from 13 tertiary colleges of education and questionnaires were administered. Out of which, $212(96 \%)$ responses were validly returned. Out of the 212 teachers, $133(63 \%)$ were males and they formed the majority of the respondents in the study. On average, the teachers were around 43 years of age ( 30 years being the minimum and 65 years being the maximum). Ninety-nine teachers (47\%) were first degree/higher national diploma (HND) holders, while 105 (50\%) were Masters' degree holders. Only 8 teachers (4\%) were doctoral degree holders. Overall, 85 respondents (40\%) had worked for a period of 2-8 years as business education teachers; while 46 (22\%) had worked for a period of 9-14 years. Also, 49 teachers (23\%) had worked for 15-20 years as business education teachers, while only 25 (12\%) had worked for 21-26 years. Only 7 teachers (3\%) had worked for a period of 27 to 33 years in the profession. Additionally, 39 teachers (18\%) were assistant lecturers/assistant instructors, while 73 (34\%) were lecturers/instructors. Also, 60 teachers (28\%) were senior lecturers/senior instructors while 24 teachers (11\%) were principal lecturers/principal instructors. On the whole, only 16 teachers $(8 \%)$ were Chief Lecturers/Chief Instructors.

\section{Research instrument}

This study utilized a structured questionnaire with items adapted from previously validated works of Venkatesh et al. (2003) and Henry and Stone $(1997,1999)$ for computer selfefficacy; Teo et al. (2008) for subjective norm; Venkatesh and Bala (2008) for perceived enjoyment; Venkatesh et al. (2003) and Davis et al. (1989) and Venkatesh and Davis (2000) for perceived usefulness.

Seven items adapted from Venkatesh et al. (2003) and Henry and Stone $(1997,1999)$ were used to measure
Table 1 Reliability coefficients of constructs at pilot study. Reproduced with permission from pilot study data collected from business education teachers in three tertiary colleges of Nigeria

\begin{tabular}{llll}
\hline S/N & Construct & $\begin{array}{l}\text { Number } \\
\text { of items }\end{array}$ & $\begin{array}{l}\text { Cronbach's alpha coef- } \\
\text { ficient for pilot study } \\
(n=30)\end{array}$ \\
\hline 1 & Computer self-efficacy & 7 & .897 \\
2 & Subjective norm & 6 & .692 \\
3 & Perceived enjoyment & 6 & .806 \\
4 & Perceived usefulness & 7 & .740 \\
& Average & & .784 \\
\hline
\end{tabular}

computer self-efficacy as a construct (Appendix). The items measured teachers' opinions on their knowledge of ICTs and their confidence in using ICTs in the classroom. To measure subjective norm, six items were also adapted by permission from Venkatesh et al. (2003) and Teo et al. (2008). The items measured teachers' perceptions of the expectations of important others regarding their use of ICTs in the classroom (Appendix). Also, six items were adapted from Venkatesh and Bala (2008) to measure perceived enjoyment (Appendix). The items measured the magnitude of teachers' enjoyment of using ICTs in the classroom. Lastly, seven items adapted from Davis et al. (1989) and Venkatesh (2000) were used to measure perceived usefulness (see Appendix). The items measured teachers' perceptions of the usefulness of ICTs in the classroom.

A pilot study was conducted on a sample of 30 respondents (who were business education teachers from three tertiary colleges of Northwestern Nigeria, namely, FCE (T) Bichi, FCE Kano, and SRCOE, Kano). The questionnaires were administered to the respondents online-via Google Drive to their e-mail address. The internal consistency of the instrument was determined using Cronbach Alpha coefficients. An overall Cronbach Alpha coefficient of 0.78 was obtained for the instrument. As shown in Table 1, all the constructs investigated in the pilot study achieved adequate reliability, with Cronbach Alpha values greater than 0.6 (Fraenkel et al. 2012; Pallant 2010). The questionnaire had 26 items to obtain information from the participants regarding their opinions on CSE (seven items), SN (six items), PE (six items), and PU (seven items). Each item was measured on a five-point Likert-type scale with the measurements ranging from $1=$ 'strongly disagree' to $5=$ 'strongly agree.' All negative items in the instrument were reversely scored (DeVellis 2003). 
Table 2 Results of mean, standard deviation, skewness, and kurtosis analysis

\begin{tabular}{llllll}
\hline Construct & No. of items & Mean & Std. deviation & Skewness & Kurtosis \\
\hline Computer self-efficacy & 7 & 3.36 & 0.70 & -0.045 & -0.557 \\
Subjective norm & 6 & 3.59 & 0.75 & -0.591 & -0.365 \\
Perceived enjoyment & 6 & 4.13 & 0.66 & -0.158 & -0.820 \\
Perceived usefulness & 7 & 4.18 & 0.54 & -0.188 & -0.704 \\
Average (mean and SD) & & 3.82 & 0.66 & & \\
\hline
\end{tabular}

\section{Results}

\section{Statistical analyses}

According to Kline (2011), data can be considered to be normally distributed if the skewness and kurtosis values are in the range between \pm 3 and \pm 10 , respectively. Table 2 shows the results of skewness and kurtosis analysis for each construct in the study.

Table 2 also shows the means and standard deviations of Nigerian business education teachers' responses on each of the variables in the study. Based on the overall mean ratings of the responses of the teachers, computer self-efficacy and subjective norm were below the average mean of $M=3.82$ $(\mathrm{SD}=0.66)$. This meant that teachers' perceptions of the expectations of important individuals towards their usage or non-usage of ICTs and their perceptions of their computer self-efficacy were comparatively low. However, teachers' high responses on perceived enjoyment and perceived usefulness implied they perceived ICTs as highly enjoyable and useful to their jobs.

\section{Confirmatory factor analysis (CFA)}

The purpose of CFA is to assess the loading between factors (items) and the observed variables they are purported to measure (Hair et al. 2010). In the process of doing this, CFA also examines construct reliability and construct validity (Lei and Wu 2007; Lomax and Schumacker 2012). This implied, CFA examines the extent to which the indicators (items/factors) capture the concepts of the constructs in a reliable and valid way (Pallant 2010).

To assess the CFA, three categories of indices are usually examined, namely, the absolute fit indices, the incremental fit indices, and the parsimony fit indices (Hair et al. 2010; Ho 2006). The purpose of the absolute fit indices is to investigate how the supporting theory/theories of the study fit(s) in with the sample data of the study, and it comprises several other sub-indices, namely, root mean square error of approximation (RMSEA) and goodness of fit indices (GFI) (Byrne 2013; Hair et al. 2010).

Existing literature suggested that when conducting factor analysis, items having factor loadings less than 0.6 and $R^{2}<0.4$ should be deleted from the measurement model except when there are valid justifications to retain them (Zainudin 2012). In this study, after implementing CFA, only 14 items were retained to measure the constructs of the study.

\section{Computer self-efficacy}

At the initial stage, seven items were included to measure computer self-efficacy but the fit indices were below the set standard. Out of the indices listed, only GFI and RMR fitted the model and the factor loadings for two indicators-(CSE2 and CSE5) were below 0.60.

High covariance was found between CSE1 $\leftrightarrow$ CSE6, $(\mathrm{M}=35.354)$ and between CSE4 $\leftrightarrow$ CSE7, $(M=19.003)$. Hence, items CSE6, CSE7, CSE2, and CSE5 were removed due to low factor loadings ( 0.58 each). After deleting the four items, all the indices of the revised model fitted excellently with the factor loadings of the items exceeding 0.60 . Additionally, the model's AVE value was satisfactory (0.512), indicating adequate convergent validity $(>0.50)$, while its CR value was 0.804 ( $>0.7)$, indicating adequate reliability of the measurement standard of the computer self-efficacy construct.

\section{Subjective norm}

At the initial stage, subjective norm had six indicators, but the model's fit indices were below the required criteria. Except for RMR all other indices in the model were inadequate. Therefore, it became necessary to modify the model in order to improve its fitness (Hair et al. 2010).

To improve the model, items SN 5 and SN 7 were deleted based on their low factor loadings, and even though item SN 4 had a high factor loading, it was deleted based on its high covariance with SN 3 as revealed in the modification index. After deleting the three indicators, all the indices of the revised model fitted, and the model's AVE and CR values became satisfactory, indicating adequate convergent validity and adequate construct reliability of the subjective norm construct (Hair et al. 2010). 


\section{Perceived enjoyment}

At the initial stage, perceived enjoyment had six indicators, and all the fit indices satisfied the required criteria. However, factor loadings for two indicators (PE4 and PE5) were below 0.60 . Hence, the two items were deleted to improve the fit indices of the model. Consequently, the model's AVE and CR values became satisfactory, indicating adequate convergent validity and adequate construct reliability.

\section{Perceived usefulness}

At the initial stage, seven items were used to measure perceived usefulness. All the conditions for the fitness of the model for perceived usefulness construct were satisfied except for RMSEA which was slightly above the cut-off value. The factor loadings for two indicators-(PU1 and PU2) - were also below 0.60. To improve the fitness of the model, items PU1 and PU2 were deleted. In addition, 'free parameter estimates' were set between PU3 and PU4 which were found to be redundant items as per their high covariance in the modification indices. The two correlated items were constrained, and all the fit indices of the model as well as the factor loadings of its indicators and the construct's AVE and CR values were satisfactory, indicating adequate convergent validity and adequate construct reliability (Zainudin 2012). However, to improve the parsimony of the model, PU4 was later removed because it had the least factor loading (.70) among the five items left. The parsimony of the model was indicated by the value of the model's RMSEA and improving the model's RMSEA was indicative of the model's propensity to measure the perceived usefulness construct with lesser number of items (Hooper et al. 2008). Hence, ultimately only four items were retained in the model to measure perceived usefulness.

\section{The measurement model}

The measurement model of this study (Fig. 2) had attained sufficient number of valid indicators for each construct. To implement CFA, each construct has to have at least three indicators, with factor loadings above .50, Average Variance Extracted (AVE) above .50, and Construct Reliability (CR) above .70 (Hair et al. 2010). These criteria were fulfilled for all the constructs investigated in the study, as shown in Table 3. The critical ratios of all the items investigated were also significant at the 0.001 level, and their squared multiple correlations $\left(R^{2}\right)$ ranged from 0.396 to 0.971 indicating the amount of variance explained by each factor (Hair et al. 2010; Schumacker and Lomax 2004; Suhr 2006).

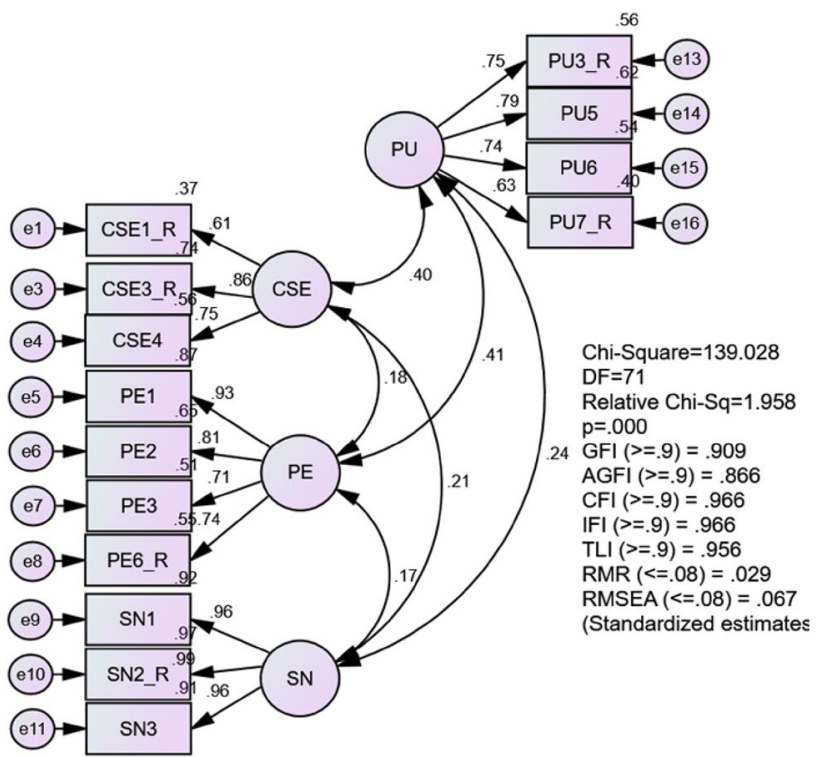

Fig. 2 Measurement Model for antecedents to teachers' perceptions of the usefulness of ICTs in business education classrooms. Reproduced with permission from data collected from business education teachers in 13 tertiary colleges of Northwestern Nigeria

\section{Test of the measurement model}

The measurement model (with 14 indicators) was tested using AVE and CR measures to determine convergent validity for all the constructs in the model. Fornell and Bookstein (1982) stated that a construct is valid when the AVE of the variance attributable to the construct in relation to the variance attributable to the measurement errors is adequate. For valid constructs, AVE values must be $\geq 0.50$, indicating adequate convergent validity. Table 3 shows that all the AVE values in the measurement model of this study were $>.50$, implying that convergent validity was achieved. Construct reliability (CR) test was also conducted on all items to assess their reliability with regard to how they measure their respective constructs. As a rule of thumb, all values must be $>.70$ (Fraenkel et al. 2012; Pallant 2010). Table 3 also shows each and every construct had valid construct reliability, ranging from 0.782 to 0.958 . This additionally satisfied the condition for convergent validity for all the constructs (Hair et al. 2010).

The discriminant validity of the constructs in the measurement model was also tested by comparing the AVE of every given construct with the squared correlations between that construct and other constructs. If the AVEs are greater than the off-diagonal elements in the corresponding rows and columns and are also greater than the squared correlations between a given construct and other constructs in the model, discriminant validity is considered to be adequate. When the value of the variance shared between a construct 
Table 3 Unstandardized and standardized regression of weights for the overall measurement model

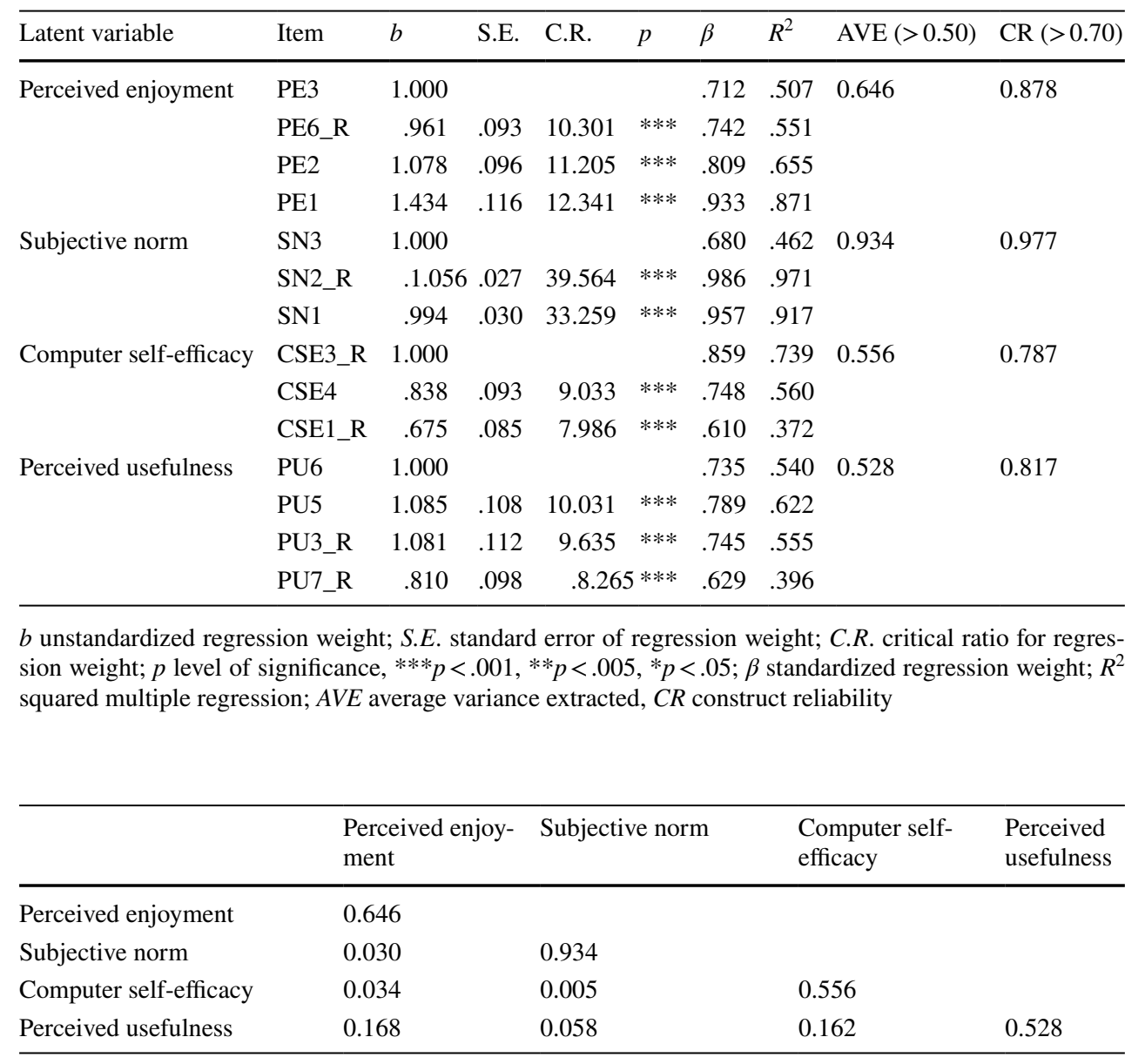

$b$ unstandardized regression weight; S.E. standard error of regression weight; $C . R$. critical ratio for regression weight; $p$ level of significance, ${ }^{* * *} p<.001,{ }^{*} p<.005,{ }^{*} p<.05 ; \beta$ standardized regression weight; $R^{2}$ squared multiple regression; $A V E$ average variance extracted, $C R$ construct reliability

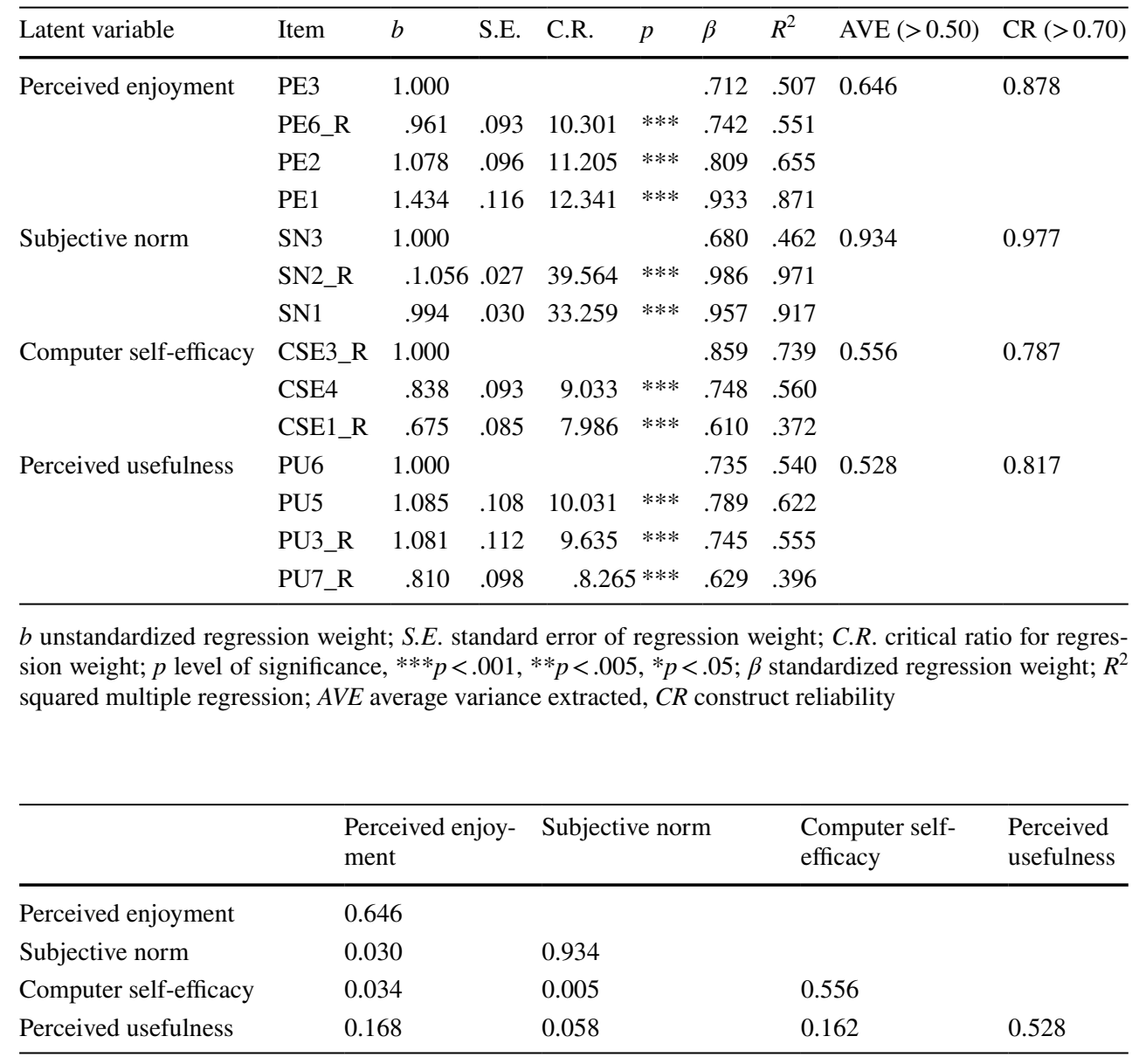

Table 4 Discriminant validity for the measurement model of the study and another construct in a model is less than the value of the variance shared by the construct with its indicators, discriminant validity is considered as being realized (Fornell and Larcker 1981).

The correlation matrix in Table 4 indicates that the AVE values in all the diagonal elements were greater than the values of the squared correlations between one construct and the other constructs in the columns of the off-diagonal elements. This suggested that all the conditions of discriminant validity were attained (Fornell and Larcker 1981).

\section{The structural model}

The structural model of this study (Fig. 3) comprised three exogenous variables, namely, CSE, PE, and SN as well as one endogenous variable, namely, PU. While the measurement model had 14 indicators, the structural model had 13 because, one item (PE3) was removed to improve the model's parsimony or simplicity in explaining teachers' perceived usefulness of technology. Hence, with 13 indicators, the structural model explained the interrelationships between business education teachers' perceived

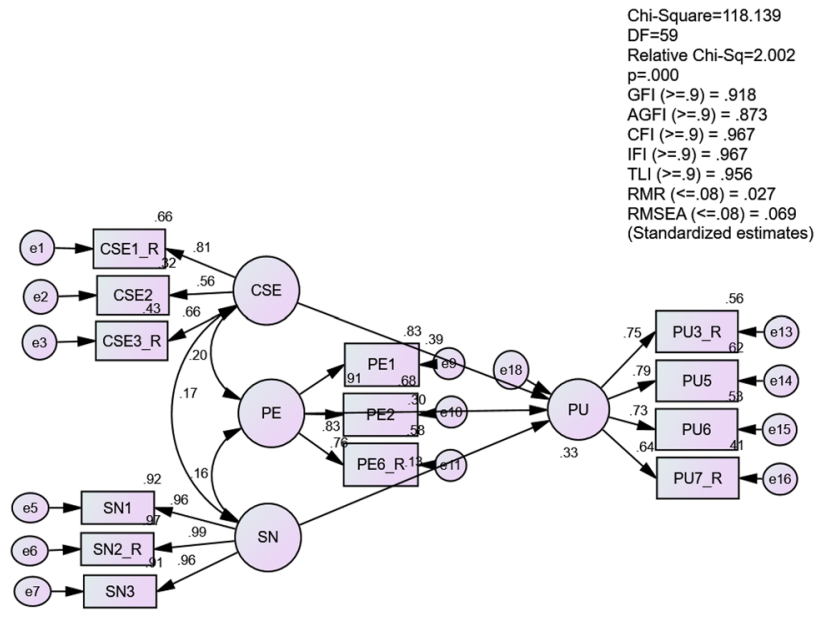

Fig. 3 Structural model for antecedents to teachers' perceptions of the usefulness of technology in business education classrooms

computer self-efficacy, perceived enjoyment of technology, perceived subjective norm, and perceived usefulness of technology in the classroom, satisfying absolute, parsimonious and incremental fit indices (Hair et al. 2010). 
The absolute fit measures indicate the extent to which the model fits with the observed covariance matrix, and the indices are $\chi^{2}$ statistics, goodness of fit index (GFI), and the RMSEA. The incremental fit measures compare the proposed model with the independence or null model, and the indices are Tucker-Lewis index (TLI), normal fit index (NFI), comparative fit index (CFI), relative fit index (RFI), and incremental fit index (IFI). In this study, the values for NFI and RFI were not reflected because the study data supported TLI, CFI, and IFI more favorably and ultimately each and every one of the indices (NFI, RFI, TLI, CFI, and IFI) were basically meant for measuring the incremental fitness of the model. Based on this, for all the constructs investigated in the study ensured that the modified models had conformed to the standard set for fit indices values on Relative $\chi^{2}$, GFI, GFI, AGFI, CFI, IFI, TLI, RMR, and RMSEA. According to the literature, relative $\chi^{2}$ should be $\leq 5.00$; GFI should be $\geq 0.90$; AGFI should be $\geq 0.90$; CFI should be $\geq 0.90$; IFI should be $\geq 0.90$; TLI should be $\geq 0.90$; RMR should be $\leq 0.08$; and RMSEA should be $\leq 0.08$ (Byrne 2013; Cheung and Rensvold 2002; Hair et al. 2010; Marsh and Hocevar 1988; Schumacker and Lomax 2010). Therefore, the overall structural model of this study met all the above-mentioned criteria for its goodness of fit, and the values were as follows: $\chi^{2}=139.028 .821, d f=71$, relative $\chi^{2}=1.958, \mathrm{GFI}=.909$, adjusted goodness of fit index; CFI $=.966$, IFI $=.966$, $\mathrm{TLI}=.956$, root mean square residual $(\mathrm{RMR})=.029$ and, RMSEA = .067 (Fig. 3; Table 5).

\section{Findings}

\section{Test of the structural model}

Results of the test for the structural model showed that out of the three hypotheses, $\mathrm{H} 1$ and $\mathrm{H} 2$ were supported while H3 was not supported. Consistent with past researches (Agarwal and Karahanna 2000; Isiyaku et al. 2015; Teo et al. 2009) the findings showed Nigerian business teachers' computer self-efficacy had a significant influence on

Table 5 Indices for models of the study

\begin{tabular}{lll}
\hline Model indices & Measurement model & Structural model \\
\hline$\chi^{2} / \mathrm{df}$ & $139.028 / 71=1.962$ & $118.139 / 59=2.002$ \\
GFI & .909 & .918 \\
CFI & .966 & .967 \\
IFI & .966 & .967 \\
TLI & .956 & .956 \\
RMR & .029 & .027 \\
RMSEA & .067 & .069 \\
\hline
\end{tabular}

Table 6 Results of the tests of hypotheses

\begin{tabular}{lllll}
\hline Hypotheses & Paths & $\beta$ & $p$ level & Results \\
\hline H1 & CSE $\rightarrow$ PU & .386 & $* * *$ & Supported \\
H2 & PE $\rightarrow$ PU & .304 & $* * *$ & Supported \\
H3 & SN $\rightarrow$ PU & .128 & .067 & Not supported \\
\hline
\end{tabular}

their perceptions of the usefulness of ICTs. The findings also revealed teachers' perceived enjoyment of ICTs had a significant influence on their perceived usefulness of ICTs. These were also consistent with findings in previous studies (e.g., Cheok and Wong 2015; Huang et al. 2015; Negahban and Chung 2014). However, the findings from this study did not support the hypothesis that Nigerian business teachers' subjective norm significantly influenced their perceived usefulness of ICTs. Details of these results are shown in Table 6.

The findings also revealed perceived enjoyment explained about $30 \%$ of the variance in teachers' perceived usefulness of technology with an $R^{2}$ of 0.304 , while computer self-efficacy explained about $39 \%$ with an $R^{2}$ of 0.386 . The least explanation of the variance in teachers' perceived usefulness of technology was $13 \%$, contributed by subjective norm with an $R^{2}$ of 0.128 . Overall, the combined effects of these three exogenous variables explained about $33 \%$ of the variance in teachers' perceived usefulness of ICTs, with an $R^{2}$ of 0.333 .

\section{Discussion of findings}

This study found computer self-efficacy and perceived enjoyment as important antecedents to Nigerian business education teachers' perceptions of the usefulness of technology in the classroom. The study showed that teachers' perceptions of the usefulness of ICTs were significantly determined by their perceptions of their abilities to use technology and their perceived enjoyment of using such technologies in the classroom. Teachers perceived ICTs as useful in their classrooms when they felt they were capable of using the tools and when they perceived the tools were enjoyable to use. These findings were consistent with the theoretical conventions of TAM and with the findings of studies such as (Igbaria and Iivari 1995; Teo et al. 2008; Huang et al. 2015; Isiyaku 2016; Isiyaku and Ayub 2016)

In this study, Nigerian business education teachers found ICTs to be enjoyable and they found pleasure in using the tools in business education. As shown in the results, teachers' high response for the perceived enjoyment construct was an indication that they highly perceived ICTs to be enjoyable for classroom purposes. This was consistent with the existing literature studies that showed perceived enjoyment of 
ICTs could influence teachers' use of ICTs in the classroom (e.g., Davis et al. 1992; Van der Heijden 2004; Venkatesh 2000; Verkasalo et al. 2010).

Although the findings of this study revealed computer self-efficacy as the strongest influence on teachers' perceptions of the usefulness of ICTs in the classroom, teachers' perceptions of their abilities for using ICTs were low, implying that teachers were not so effectual at using computers for classroom purposes. This finding was consistent with the findings by Daramola (2015) that teachers in Nigerian tertiary institutions lacked technical expertise on computers to enable them to teach students with ICTs. The finding was also consistent with Ajayi (2008) findings which reported that teachers in Colleges of Education in South West Nigeria were incompetent at implementing ICTs in the classroom.

However, while this study did not show the influence of subjective norm on teachers' perceptions of the usefulness of technology in the classroom, it had revealed that teachers expected more support from their school authorities concerning their use of ICTs in the classroom. This finding was consistent with Prasad et al.'s (2015) findings that lack of support from school authorities was among the barriers to the use of ICTs among teachers in India. In the same vein, findings in Ajayi's (2008) study showed most teachers in Colleges of Education around South West Nigeria perceived they lacked adequate support to use ICTs in their classrooms.

This study also revealed that teachers' perceived that ICTs addressed their teacher-related needs and that by using them in the classroom increased their productivity and effectiveness. This implied they perceived ICTs as highly useful for their classroom purposes. These findings were supported in the literature (e.g., Anandarajan et al. 2002; Davis 1989; Pynoo and van Braak 2014; Schepers and Wetzels 2007; Teo 2011). Therefore, while it is important that school authorities provide teachers with induction training on the use of technology, it is also important that teachers optimize the usability of such technologies to their advantage.

In the study model, only $33 \%$ of the variance explained Nigerian business education teachers' perceived usefulness of technology. Therefore, there were other important variables associated with the variance in business education teachers' perceptions of the usefulness of technology in the classroom which were not investigated in this study. Subjective norm did not predict teachers' perceptions of the usefulness of technology, leaving a significant gap in explaining teachers' perceptions of the usefulness of technology. Teachers might not fully appreciate the usefulness of technology if they did not perceive they were expected to use such technologies in the classroom.

\section{Summary}

Consistent with the findings of past researches, the current study found computer self-efficacy and perceived enjoyment as important antecedents to teachers' perceptions of the usefulness of technology in the classroom. Similar finding was revealed in a study conducted among 592 teachers from schools in Singapore (Teo 2011). Hypothetically, Teo (2011) postulated that in locations where teachers were not compelled to use ICTs, the influence of important others may not significantly predict how technology is used in the classroom. In sum, this study upholds Teo's (2011) assertion.

\section{Suggestions}

As this study has shown the weakness of business education teachers in using ICTs in Nigerian tertiary colleges, it is imperative for Government agencies in Nigeria to train teachers on how to integrate technology in their teaching roles. Similarly, to ensure that teachers use technology in the classroom, they should be provided with ICT guidance that could help them with ICT difficulties when administering their lessons. To support these suggestions, Kim, Bonk and Teng (2009) admitted that guidance on how to implement technologies related to emerging instructional strategies was fundamental to the future of the Asia-Pacific region (i.e., China, South Korea, Taiwan, United States, and the United Kingdom).

Consistent with what has been said above, providing ubiquitous internet access in schools could enable teachers to freely access and use ICTs to enhance teacher-learner interactions, conduct research, create, and share contents and to positively facilitate students' learning. Also, since business teachers in Nigerian tertiary institutions enjoy using ICTs in the classroom and consider the tools as useful for teaching, it is appropriate to ensure that adequate opportunity is given to Nigerian teachers to use ICTs in the classroom and beyond.

\section{Conclusion}

Computer self-efficacy, subjective norm, perceived enjoyment, and perceived usefulness were investigated in this study because of the roles the variables played in TAM-being important determinants of individuals' intentions to accept or reject technology. Whereas literature had reported the importance of these variables in determining teachers' intentions and behavioral performances in the use of ICTs, there was little or no report reflecting Nigerian/Africa research in regard to these variables. Drawing from Lee (2016), educational authorities/ 
researchers in Nigeria should review their policies with the perspective of answering important questions such as "how can teachers get more access to technology?," "how can the access be widened?," "how can technology be successfully adopted in the classroom?," and "how can the country draw examples from countries in the regions of USA, UK, and South East Asia to overcome issues and challenges in formulating and implementing contemporary educational/technological policies?."

Although the current study had added an African perspective of technology acceptance research to literature, it was not without limitations. Using self-reported scales to measure the variables in the study raised the possibility of interference of misguided motives, instincts, and bias in respondents' responses. Therefore, replication and further studies using experimental or qualitative approaches are needed to examine and detect other variables of interest such as the effects of job relevance and facilitating conditions on teachers' perceptions of the usefulness of technology for teaching and learning.

Open Access This article is distributed under the terms of the Creative Commons Attribution 4.0 International License (http://creativeco mmons.org/licenses/by/4.0/), which permits unrestricted use, distribution, and reproduction in any medium, provided you give appropriate credit to the original author(s) and the source, provide a link to the Creative Commons license, and indicate if changes were made.

\section{Appendix}

See Table 7.

Table 7 Constructs and items statements

\begin{tabular}{|c|c|c|}
\hline $\mathrm{S} / \mathrm{N}$ & Code & Item statements \\
\hline \multicolumn{3}{|c|}{ Computer self-efficacy } \\
\hline 1 & CSE1 & I don't have enough knowledge about ICTs to get my teaching job done ${ }^{a}$ \\
\hline 2 & CSE2 & $\begin{array}{l}\text { I could complete a job or task using the computer without calling someone to help me even in the face of } \\
\text { difficulties }\end{array}$ \\
\hline 3 & CSE3 & I don't feel confident using ICT tools for classroom interactions ${ }^{\mathrm{a}}$ \\
\hline 4 & CSE4 & I use ICTs in facilitating business education instructions as much as possible \\
\hline 5 & CSE5 & Compared to other teachers in business education, I know a lot about ICTs \\
\hline 6 & CSE6 & At work, I feel more competent with ICTs than most other teachers in business education \\
\hline 7 & CSE7 & I feel confident in using the computer to teach business education contents \\
\hline \multicolumn{3}{|c|}{ Subjective norm } \\
\hline 1 & SN1 & People who are important to me think that I should use ICTs in the classroom \\
\hline 2 & SN2 & The senior management of this institution has been helpful in the use of ICTs for classroom instructions \\
\hline 3 & SN3 & My colleagues encourage me to use ICTs in the classroom \\
\hline 4 & SN4 & People who influence my behavior think I should use ICTs to facilitate classroom instructions \\
\hline 5 & SN5 & I use ICTs because of the proportion of my colleagues who use them \\
\hline 6 & SN6_R & People whose opinions I value will not encourage me to use ICTs for classroom functions ${ }^{a}$ \\
\hline \multicolumn{3}{|c|}{ Perceived enjoyment } \\
\hline 1 & PE1 & I find ICTs to be enjoyable \\
\hline 2 & PE2 & The actual process of using ICTs for teaching is pleasant \\
\hline 3 & PE3 & I have fun using ICTs in business education classrooms \\
\hline 4 & PE4 & Using ICT tools for teaching is as natural as play \\
\hline 5 & PE5 & Using ICTs for setting tests and examinations in business education is pleasurable \\
\hline 6 & PE6 & Using ICTs for teaching is not satisfying ${ }^{\mathrm{a}}$ \\
\hline \multicolumn{3}{|c|}{ Perceived usefulness } \\
\hline 1 & PU1 & ICTs address my teacher-related needs \\
\hline 2 & PU2 & Using ICTs enables me to accomplish teaching tasks more quickly \\
\hline 3 & PU3 & Using ICTs does not improve my performance in classroom functions ${ }^{\mathrm{a}}$ \\
\hline 4 & PU4 & Using ICTs increases my productivity as a business education teacher \\
\hline 5 & PU5 & Using ICTs enhances my effectiveness as a teacher in general \\
\hline 6 & PU6 & ICTs support critical aspects of teaching and learning business education contents \\
\hline 7 & PU7 & I find ICTs to be not useful for teaching ${ }^{\mathrm{a}}$ \\
\hline
\end{tabular}

${ }^{\mathrm{a}}$ Reversed items 


\section{References}

Adams, J., Khan, H. T., \& Raeside, R. (2014). Research Methods for Business and Social Science Students. India: SAGE Publications.

Adedoja, G., Adelore, O., Egbokhare, F., \& Oluleye, A. (2013). Learners' acceptance of the use of mobile phones to deliver tutorials in a distance learning context: A case study at the University of Ibadan. The African Journal of Information Systems, 5(3), 3.

Agarwal, R., \& Karahanna, E. (2000). Time flies when you're having fun: Cognitive absorption and beliefs about information technology usage. MIS Quarterly, 24(4), 665-694.

Agbonlahor, R. O. (2008). Individual characteristics as correlates of attitudes to information technology among Nigerian University lecturers. African Journal of Library, Archives and Information Science, 18(2), 131-147.

Ajayi, A. (2008). Towards effective use of Information and Communication Technology (ICT) for teaching in Nigerian Colleges of Education. Asian Journal of Information Technology, 7(5), 210-214.

Ajzen, I. (1985). From intentions to actions: A theory of planned behavior. In J. Kuhl \& J. Beckmann (Eds.), Action control (pp. 11-39). Berlin: Springer.

Ajzen, I. (1991). The theory of planned behavior. Organizational Behavior and Human Decision Processes, 50(2), 179-211.

Al-Haderi, S. M. S. (2013). The effect of self-efficacy in the acceptance of information technology in the public sector. International Journal of Business and Social Science, 4(9), 188-198.

Anandarajan, M., Igbaria, M., \& Anakwe, U. P. (2002). IT acceptance in a less-developed country: Motivational factor perspective. International Journal of Information Management, 22(1), 47-65.

Anunobi, V. N. (2015). A study of the Information and Communication Technology use among student-teachers in universities in North Central Nigeria. Journal of Information and Knowledge Management, 5(1), 106-111.

Arekete, S., Ifinedo, P., \& Akinnuwesi, B. A. (2014). Antecedent factors to end-users' symbolic acceptance of enterprise systems: An analysis in Nigerian organizations. Proceedings of 6th International Conference on Adaptive Science \& Technology (ICAST) (pp. 1-8). Covenant University, Ota: IEEE.

Artino, A. R. Jr. (2007). Online military training: Using a social cognitive view of motivation and self-regulation to understand students' satisfaction, perceived learning, and choice. Quarterly Review of Distance Education, 8(3), 191-202.

Asenso-Okyere, K., \& Mekonnen, D. A. (2012). The importance of ICTs in the provision of information for improving agricultural productivity and rural incomes in Africa. United Nations Development Programme (UNDP) Working Paper: (2012-2015), 1-32.

Asogwa, E. B. (2013). Electronic government as a paradigm shift for efficient public services: Opportunities and challenges for Nigerian Government. Library Hi Tech, 31(1), 141-159.

Averweg, U. R. (2008). Information technology acceptance in South Africa: An investigation of perceived usefulness, perceived ease of use, and actual system use constructs. The African Journal of Information Systems, 1(1), 4.

Ayub, A. F. M., Dansarki, D. I., Wong, S. L., \& Nida, K. M.(2016). Examination of factors that influence science teachers' attitudes toward using information and communication technologies for teaching and learning. Proceedings of the 24th International Conference on Computers in Education (ICCE) (pp. 567-572). Mumbai: ICCE.

Becker, H. J. (2001). How are teachers using computers for instruction? Paper presented at the 2001 Annual Meeting of the American Educational Research Association, Seattle.
Bhatti, T. (1970). Exploring factors influencing the adoption of mobile commerce. Journal of Internet Banking and Commerce, 12(3), $2-13$.

Bingimlas, K. A. (2009). Barriers to the successful integration of ICT in teaching and learning environments: A review of the literature. Eurasia Journal of Mathematics, Science \& Technology Education, 5(3), 235-245.

Byrne, B. M. (2013). Structural equation modeling with AMOS: Basic concepts, applications, and programming. New York: Routledge.

Cheok, M. L., \& Wong, S. L. (2015). Predictors of E-Learning satisfaction in teaching and learning for school teachers: A literature review. International Journal of Instruction, 8(1), 75-90.

Cheung, G. W., \& Rensvold, R. B. (2002). Evaluating goodness-of-fit indexes for testing measurement invariance. Structural Equation Modeling, 9(2), 233-255.

Compeau, D. R., \& Higgins, C. A. (1995). Computer self-efficacy: Development of a measure and initial test. MIS Quarterly, 19, 189-211.

Dansarki, I. D., Ayub, A. F. M., \& Kadir, S. A. (2014) Modeling ICT usage in business education faculties of tertiary colleges in Nigeria. Proceedings of the Australian Academy of Business and Social Sciences Conference (in partnership with The Journal of Developing Areas, USA) (pp. 235-243). Kuala Lumpur.

Daramola, F. O., Yusuf, M. O., \& Oyelekan, O. S. (2015). Information and Communication Technology literacy among student-teachers in universities in Nigeria. Malaysian Online Journal of Educational Technology, 3(4), 13-22.

David, O. N. (2012). Using mixed method approach to understand acceptance and usage of ICT in Nigerian public universities. International Journal of Computers \& Technology, 2(3), 47-63.

Davis, F. (1989). Perceived usefulness, perceived ease of use, and user acceptance of Information Technology. MIS Quarterly, 13(3), 319-340. https://doi.org/10.2307/249008.

Davis, F., Bagozzi, R., \& Warshaw, P. (1989). User acceptance of computer technology: A comparison of two theoretical models. Management Science, 35(8), 982-1003.

Davis, F., Bagozzi, R., \& Warshaw, P. (1992). Extrinsic and intrinsic motivation to use computers in the workplace. Journal of Applied Social Psychology, 22(14), 1111-1132.

Dawes, L. (2001). What stops teachers from using new technology. In M. Leask (Ed.), Issues in teaching using ICT. London: Taylor and Francis.

DeVellis, R. F. (2003). Scale development: Theory and applications. Newbury Park, CA: Sage.

Dziuban, C. D., Hartman, J. L., Cavanagh, T. B., \& Moskal, P. D. (2011). Blended courses as drivers of institutional transformation. In A. Kitchenham (Ed.), Blended learning across disciplines: Models for implementation (pp. 17-37). Hershey, PA: IGI Global.

Echeng, R., \& Usoro, A. (2014). Empirical study in Nigeria on effective implementation of Web 2.0 technology tools in learning: Case study of three Nigerian higher institutions. Proceedings of Science and Information Conference (SAI) 2014 (pp. 927-932). London: IEEE.

Erasmus, E., Rothmann, S., \& Van Eeden, C. (2015). A structural model of technology acceptance. SA Journal of Industrial Psychology, 41(1), 01-12.

Ertmer, P. A. (2005). Teacher pedagogical beliefs: The final frontier in our quest for technology integration. Educational Technology Research and Development, 53(4), 25-39.

Fishbein, M., \& Ajzen, I. (1975). Belief, attitude, intention and behavior: An introduction to theory and research. Reading, MA: Addison-Wesley.

Fornell, C., \& Bookstein, F. L. (1982). Two structural equation models: LISREL and PLS applied to consumer exit-voice theory. Journal of Marketing Research, 19(4), 440-452. 
Fornell, C., \& Larcker, D. F. (1981). Evaluating structural equation models with unobservable variables and measurement error. Journal of Marketing Research, 18(1), 39-50.

Fraenkel, J. R., Wallen, N. E., \& Hyun, H. H. (Eds.). (2012). How to design and evaluate research in education (8th edn.). New York: McGraw-Hill.

French, J. R. P. Jr., \& Raven, B. (1959). The bases of social power. In D. Cartwright (Ed.), Studies in social power (pp. 150-167). Oxford: University Michigan.

Hair, J., Black, W., Babin, B., \& Anderson, R. (2010). Multivariate data analysis. London: Pearson Higher Education.

Henry, J. W., \& Stone, R. W. (1997). The development and validation of computer self-efficacy and outcome expectancy scales in a nonvolitional context. Behavior Research Methods, Instruments, \& Computers, 29(4), 519-527.

Henry, J. W., \& Stone, R. W. (1999). The impacts of end-user gender, education, performance, and system use on computer selfefficacy and outcome expectancy. Southern Business Review, 25(1), 10-16.

Higgins, S., \& Moseley, D. (2001). Teachers' thinking about information and communications technology and learning: Beliefs and outcomes. Teacher Development, 5(2), 191-210.

Ho, R. (2006). Handbook of univariate and multivariate data analysis and interpretation with SPSS. Boca Raton: Chapman and Hall/CRC Press.

Hooper, D., Coughlan, J., \& Mullen, M. (2008). Structural equation modelling: Guidelines for determining model fit. Electronic Journal of Business Research Methods, 6(1), 53-60.

Huang, Y.-F., Kuo, F.-Y., Luu, P., Tucker, D., \& Hsieh, P.-J. (2015). Hedonic evaluation can be automatically performed: An electroencephalography study of web site impression across two cultures. Computers in Human Behavior, 49, 138-146.

Ibrahim, R., Hilles, S. M., Adam, S. M., Jamous, M. M., \& Yafooz, W. M. (2016). Theoretical framework formation for e-government services evaluation: Case study of the Federal Republic of Nigeria. Indian Journal of Science and Technology. https:// doi.org/10.17485/ijst/2016/v9i37/94575.

Igbaria, M., \& Iivari, J. (1995). The effects of self-efficacy on computer usage. Omega, 23(6), 587-605.

Iloanusi, N. O., \& Osuagwu, C. C. (2009). ICT in education: Achievements so far in Nigeria. In A. Méndez-Vilas, A. Solano, J. A. Martín, Mesa, González, J. Mesa \& González (Eds.), Research, reflections and innovations in integrating ICT in education (pp. 1331-1335). Badajoz: Formatex.

International Telecommunication Union (2012). Measuring the information society. Geneva: ITU.

International Telecommunication Union (2013). Measuring the information society. Geneva: ITU.

International Telecommunication Union (2014). Manual for measuring ICT access and use by households and individuals. Geneva: ITU.

Isiyaku, D. D. (2016). Predictive modelling of the effects of perceived usefulness and perceived ease of use on teacher's use of ICTs in tertiary colleges of Northwestern Nigeria. African Scholar: Journal of Contemporary Education Research (AJCER), 5(1), 136-151.

Isiyaku, D. D., \& Ayub, A. F. M. (2016), Modeling the effects of job relevance, facilitating conditions, perceived usefulness and perceived ease of use on teachers' intention of using technology in tertiary schools of LDCs. Proceedings of the 24th International Conference on Computers in Education. (pp. 43-50). Mumbai: ITT.

Isiyaku, D. D., Ayub, A. F. M., \& Kadir, S. A. (2013) Utilizing Information Communication Technologies for facilitating business education instructions in Nigeria. Paper presented at the Graduate Research in Education Seminar.
Isiyaku, D. D., Ayub, A. F. M., \& Kadir, S. A. (2015). Empirical modeling of Information Communication Technology usage behaviour among business education teachers in tertiary colleges of a developing country. South African Journal of Education (SAJE), $35(4), 1-8$.

Kadel, R. (2005). How teacher attitudes affect technology integration. Learning \& Leading with Technology, 32(5), 34-35.

Kale, U., \& Goh, D. (2014). Teaching style, ICT experience and teachers' attitudes toward teaching with Web 2.0. Education and Information Technologies, 19(1), 41-60.

Karisiddappa, C. R. (2004). Literacy concepts in the LIS: Information literacy and capability building. International Workshop on Democratization of Information: Focus on Libraries. Retrieved August 22, 2016, from http://www.nigd.org/libraries/mumbai/ reports/article-9.pdf.

Keengwe, J. (2007). Faculty integration of technology into instruction and students' perceptions of computer technology to improve student learning. Journal of Information Technology Education, $6,169-180$.

Kelman, H. C. (1958). Compliance, identification, and internalization: Three processes of attitude change. The Journal of Conflict Resolution, 2(1), 51-60.

Kelman, H. C. (1961). Processes of opinion change. Public Opinion Quarterly, 25(1), 57-78.

Kim, K. J., Bonk, C. J., \& Teng, Y. T. (2009). The present state and future trends of blended learning in workplace learning settings across five countries. Asia Pacific Education Review, 10(3), 299-308.

Kline, R. B. (2011). Principles and practice of structural equation modeling. New York: Guilford Press.

Larkin, T. L., \& Belson, S. (2005). Blackboard technologies: A vehicle to promote student motivation and learning in physics. Journal of STEM Education, 6(1/2), 14-27.

Lee, M. N. (2016). Contemporary education policies in Southeast Asia: common philosophical underpinnings and practices. Asia Pacific Education Review, 17(3), 465-478.

Lee, Y., Kozar, K. A., \& Larsen, K. R. (2003). The technology acceptance model: Past, present, and future. Communications of the Association for Information Systems, 12(1), 50.

Legris, P., Ingham, J., \& Collerette, P. (2003). Why do people use information technology? A critical review of the technology acceptance model. Information \& Management, 40(3), 191-204.

Lei, P. W., \& Wu, Q. (2007). Introduction to structural equation modeling: Issues and practical considerations. Educational Measurement: Issues and Practice, 26(3), 33-43.

Lomax, R. G., \& Schumacker, R. E. (2012). A beginner's guide to structural equation modeling. New York: Routledge Academic.

Lowerison, G., Sclater, J., Schmid, R. F., \& Abrami, P. C. (2006). Student perceived effectiveness of computer technology use in postsecondary classrooms. Computers \& Education, 47(4), 465-489.

Marsh, H. W., \& Hocevar, D. (1988). A new, more powerful approach to multitrait-multimethod analyses: Application of second-order confirmatory factor analysis. Journal of Applied Psychology, 73(1), 107.

Mathieson, K. (1991). Predicting user intentions: comparing the technology acceptance model with the theory of planned behavior. Information Systems Research, 2(3), 173-191.

Mbaba, A., \& Shema, I. (2012). Analysis of the frequency of academic staff and students use of Information and Communication Technology (ICT). Mediterranean Journal of Social Sciences, 3(14), 91-97.

Mudasiru, Y., \& Modupe, B. (2011). Student-teachers' competence and attitude towards Information and Communication Technology: A case study in a Nigerian University. Contemporary Educational Technology, 2(1), 18-36. 
Negahban, A., \& Chung, C. H. (2014). Discovering determinants of users perception of mobile device functionality fit. Computers in Human Behavior, 35, 75-84.

Oghogho, I., \& Ezomo, P. (2013). ICT for national development in Nigeria: Creating an enabling environment. International Journal of Engineering, 3(2), 2305-8269.

Olakulehin, F. K. (2007). Information and Communication Technologies in teacher training and professional development in Nigeria. Turkish Online Journal of Distance Education, 8(1).**

Ololube, N. P. (2014). Managing and planning technology usage and integration in teacher education programs in an emergent nation. In B. F. Adeoye (Ed.), Effects of information capitalism and globalization on teaching and learning (pp. 96-110). Hershey, PA: IGI Publication.

Onyia, C., \& Offorma, G. C. (2011). Learning style preferences of Nigerian university undergraduates: Implications for new faculty development model. Learning in Higher Education, 7(2), $145-165$.

Pallant, J. (2010). SPSS survival manual: A step by step guide to data analysis using SPSS. Philadelphia, PA: Open University Press.

Pearman, C. J., \& Chang, C. W. (2010). Scaffolding or distracting: CD-ROM storybooks and young readers. TechTrends, 54(4), 52.

Pituch, K. A., \& Lee, Y. (2006). The influence of system characteristics on e-learning use. Computers \& Education, 47(2), 222-244.

Prasad, C. V., Lalitha, P., \& Srikar, P. (2015). Barriers to the use of Information and Communication Technology (ICT) in secondary schools: Teacher's Perspective. Journal of Management Research, 7(2), 190-208.

Pynoo, B., \& van Braak, J. (2014). Predicting teachers' generative and receptive use of an educational portal by intention, attitude and self-reported use. Computers in Human Behavior, 34, 315-322.

Reyes, V. C. Jr., \& Kheng, C. C. S. (2015). School stakeholders' experience with navigating ICT policy reforms in Singapore. International Journal of Information and Communication Technology Education (IJICTE), 11(4), 83-96.

Schepers, J., \& Wetzels, M. (2007). A meta-analysis of the technology acceptance model: Investigating subjective norm and moderation effects. Information \& Management, 44(1), 90-103.

Schumacker, E., \& Lomax, R. (2010). Structural equation modeling. New York: Routledge, Taylor \& Francis Group.

Schumacker, R. E., \& Lomax, R. G. (2004). A beginner's guide to structural equation modeling. New Jersey: Lawrence Erlbaum Associates Publishers.

Sugar, W., Crawley, F., \& Fine, B. (2004). Examining teachers' decisions to adopt new technology. Journal of Educational Technology \& Society, 7(4), 201-213.

Suhr, D. D. (2006). Exploratory or confirmatory factor analysis? (pp. 1-17). Cary: SAS Institute.

Sun, H., \& Zhang, P. (2006). Causal relationships between perceived enjoyment and perceived ease of use: An alternative approach. Journal of the Association for Information Systems, 7(9), 24.

Tan, S. C., Cheah, H. M., Chen, W., \& Choy, D. (2017). Insights and learning from ICT integration in education in Singapore. In S. H. Tan, H. M. Cheah, W. Chan \& D. Choy (Eds.), Pushing the frontier: A cohesive system-wide approach to integrating ICT into education (pp. 129-141). Singapore: Springer.

Tang, T. L. P., \& Austin, M. J. (2009). Students' perceptions of teaching technologies, application of technologies, and academic performance. Computers \& Education, 53(4), 1241-1255.

Teo, T. (2010). Examining the influence of subjective norm and facilitating conditions on the intention to use technology among preservice teachers: a structural equation modeling of an extended technology acceptance model. Asia Pacific Education Review, $11(2), 253-262$.
Teo, T. (2011). Factors influencing teachers' intention to use technology: Model development and test. Computers \& Education, 57(4), 2432-2440. https://doi.org/10.1016/j.compe du.2011.06.008

Teo, T., Lee, C. B., \& Chai, C. S. (2008). Understanding pre-service teachers' computer attitudes: Applying and extending the technology acceptance model. Journal of Computer Assisted Learning, 24(2), 128-143.

Teo, T., Lee, C. B., Chai, C. S., \& Wong, S. L. (2009). Assessing the intention to use technology among pre-service teachers in Singapore and Malaysia: A multigroup invariance analysis of the Technology Acceptance Model (TAM). Computers \& Education, 53(3), 1000-1009. https://doi.org/10.1016/j.compe du.2009.05.017.

Ubulom, W., Enyekit, E., \& Onuekwa, F. (2011). Analysis of ICT accessibility and utilization in teaching of business studies in secondary schools in Andoni Local Government Area of Rivers State. Journal of Academic Research International, 1(3), 349-354.

Umoru, T. A. (2012). Barriers to the use of information and communication technologies in teaching and learning business education. American Journal of Business Education (AJBE), 5(5), 575.

United Nations Educational Scientific and Cultural Organization (2010). ICT transforming education: A regional guide. Bangkok: Asia and Pacific Regional Bureau for Education.

Van der Heijden, H. (2004). User acceptance of hedonic information education systems. MIS Quarterly, 28(4), 695-704.

Venkatesh, V. (2000). Determinants of perceived ease of use: Integrating control, intrinsic motivation, and emotion into the technology acceptance model. Information Systems Research, 11(4), 342-365.

Venkatesh, V., \& Bala, H. (2008). The technology acceptance model 3 and a research agenda on interventions. Decision Sciences, 39(2), 273-315.

Venkatesh, V., Croteau, A. M., \& Rabah, J. (2014). Perceptions of the effectiveness of instructional uses of technology in higher education in an era of Web 2.0. Proceedings of the 47th Hawaii International Conference on System Sciences (HICSS) (pp. 110-119). Hawaii: IEEE.

Venkatesh, V., \& Davis, F. D. (1996). A model of the antecedents of perceived ease of use: Development and test. Decision Sciences, 27(3), 451-481.

Venkatesh, V., \& Davis, F. D. (2000). A theoretical extension of the technology acceptance model: Four longitudinal field studies. Management Science, 46(2), 186-204.

Venkatesh, V., \& Morris, M. G. (2000). Why don't men ever stop to ask for directions? Gender, social influence, and their role in technology acceptance and usage behavior. MIS Quarterly, 24, 115-139.

Venkatesh, V., Morris, M. G., Davis, G. B., \& Davis, F. D. (2003). User acceptance of information technology: Toward a unified view. MIS Quarterly, 27(3), 425-478.

Verkasalo, H., López-Nicolás, C., Molina-Castillo, F. J., \& Bouwman, H. (2010). Analysis of users and non-users of smartphone applications. Telematics and Informatics, 27(3), 242-255.

Windschitl, M., \& Sahl, K. (2002). Tracing teachers' use of technology in a laptop computer school: The interplay of teacher beliefs, social dynamics, and institutional culture. American Educational Research Journal, 39(1), 165-205.

Yusuf, M. O., \& Yusuf, H. T. (2009). Educational reforms in Nigeria: The potentials of Information and Communication Technology (ICT). Educational Research and Reviews, 4(5), 225-230.

Zainudin, A. (2012). Structural equation modelling using Amos Graphic. Shah Alam: Universiti Teknologi MARA Publication Centre (UPENA). 